DePauw University

Scholarly and Creative Work from DePauw University

$10-20-2017$

\title{
Toward an educational sphereology: Air, wind, and materialist pedagogy
}

Derek R. Ford

DePauw University, derekford@depauw.edu

Follow this and additional works at: https://scholarship.depauw.edu/educ_facpubs

Part of the Education Commons

\section{Recommended Citation}

This in an accepted manuscript of an article published by Taylor \& Francis in: Ford, Derek R. and Weili Zhao, 2017. "Toward an educational sphereology: Air, wind, and materialist pedagogy." Educational Philosophy and Theory(October 20). https://doi.org/10.1080/00131857.2017.1389269

This Article is brought to you for free and open access by the Education Studies at Scholarly and Creative Work from DePauw University. It has been accepted for inclusion in Education Studies Faculty publications by an authorized administrator of Scholarly and Creative Work from DePauw University. 


\section{Toward an educational sphereology: Air, wind, and materialist pedagogy}

It's not uncommon for people to make reference to atmospheres, including in relationship with educational spaces. For example, teachers often talk about wanting to create particular types of atmospheres in their classrooms: 'risky,' 'safe,' 'critical,' 'transformative,' and so on. And in their evaluations of classes, we have had students mention the atmospheres of our classrooms. They have labelled these atmospheres of ours 'comfortable,' 'cool,' and even 'weird' or 'strange.' If pressed to articulate precisely what we mean by these statements, we might come up short. Oftentimes, that is, the atmosphere is a shorthand term for things that we can't quite explain, and a gesture toward a certain kind of teaching or learning ambience: 'I can't put my finger on it, it was just a tense atmosphere.' In this article, we want to take the notion of the educational atmosphere seriously, as a literal and figurative object, and an object that blurs the lines between the literal and the figural. This, in turn, leads us to explore air as a style of reasoning and bears down on and facilitates particular forms of teaching, learning, and teacherstudent engagements.

In this article, we proffer an educational sphereology by drawing implications from Western and Chinese literature on air and wind, the latter defined as air in movement. We pursue this task in three phases. First, we examine the Western literature to see the possible strings of thought that would help us reinvigorate the element of air/atmosphere as a foundational component of an educational sphere. Second, we historicize the Chinese notion of wind as a style of reasoning which structures the ancient Chinese cosmology, tempo-spatiality, teaching, and governing into a grid of intelligibility. Third, we argue for a bracketing of a trap of philology and a signifier-signified representational logic through reconceptualizing the atmosphere as a thing that blurs the material-figural boundary and that pushes into a new genre of educational life. We assemble these diverse resources not to provide new ground for educational philosophy and theory, but to offer aerial axioms for those working to co-produce educational atmospheres.

\section{Sloterdijk's spherical ontology}

Education always takes place in some space, and thus space has always been a central concern for educational philosophy. This has tended to be relegated to concerns of design and architecture, however. Educational philosophers first began to theorize space outside of these confines in the mid-1990s, and Michael Peters (1996) book, Poststructuralism, politics and education was the first work that we have found to do so. Drawing on Foucault's assertion that 'space is fundamental to any exercise of power,' Peters surveys the work of a few critical geographers and architects and poses 'a series of theoretical concerns for a critical theory of education that takes space and the politics of space seriously' (p. 95). The primary lesson drawn is that we need to attend to the myriad ways in which space comes to be as a result of political processes. Since then, various educational scholars have taken up Peters' call, which in many ways inaugurated a 'spatial turn' in education (e.g., Ferrare and Apple, 2010; Ford, 2016, 2017; Hung and Stables, 2011; Ringrose, 2011; Usher, 2002; Wubbena, 2017). This literature has attended to space as a social phenomenon that is continually constructed and reconstructed through the lenses of political economy, history, globalization studies, post-structuralism, feminism, post-humanism, phenomenology, and critical pedagogy. This work has investigated the spaces of schools, universities, and classrooms, as well as how these relate to larger spaces 
(like cities) and spatial processes (like globalization). We locate our project as an extension of this spatial turn, as we move to that which necessarily fills space to make it inhabitable.

To begin this particular project, we want to call on Peter Sloterdijk's theory of spheres, a grand historical narrative constructed in response to a noted absence in Heidegger's notion of Dasein. Sloterdijk observes that, while Heidegger addressed being-in-the-world, he never accounted for precisely what being is in when it is in the world. For subjects are never just there, but are always contained in something. This leads Sloterdijk to propose his sphereological study of globalization and history, a hypothesis that being-in-the-world is always a being-in-somespherical-form and a being-in-the-air (Sloterdijk and Heinrichs, 2001/2011). At the most fundamental level of abstraction, he argues, spheres are 'air conditioning systems in whose construction and calibration, for those living in real coexistence, it is out of the question not to participate' (Sloterdijk, 1998/2011, p. 46). He contends that these systems are foundational in social construction, but that while 'humans create their own climate,' they don't to so 'according to free choice, however, but under preexisting, given, and handed-down conditions' (pp. 46-48).

This last line, of course, resonates with Marx's (1963) famous assertion that humans 'make their own history, but they do not make it just as they please... but under circumstances directly encountered, given and transmitted from the past' (p. 15). The point is that for humans to be they must participate in the co-production of spheres in which to be, and that this coproduction will take place under actually-existing realities, not fantastical or idealistic projections. In fact, spheres arise in part as responses to those conditions. As Sloterdijk (1998/2011) remarks,

for humans, being-in-spheres constitutes the basic relationship - admittedly, one that is infringed upon from the start by the non-interior world, and must perpetually assert itself against the provocation of the outside, restore itself and increase. In this sense, spheres are by definition also morpho-immunological constructs. Only in immune structures that form interiors can humans continue their generational processes and advance their individuations. (pp. 45-46)

Viewed in terms of a sphereological process then, globalization is not a formation that was initiated or even accelerated in the $20^{\text {th }}$ century (usually located in academic literature around 1948), and it isn't the result of intensified networks of communications, high-speed transportation technologies, or new forms of political association. Globalization rather begins 'in the rationalization of the world's structure by the ancient cosmologists, who were the first to construct with conceptual, or rather morphological seriousness the totality of the existent in a spherical form, and presented this edifying construct of order to the intellect for viewing' (Sloterdijk, 2003/2013, p. 8). Broadly speaking, Greek thought conceived of the universe as a whole, as a finished totality. The earth was placed in the center of this whole, where it was protected by the cosmos. This phase of spherical globalization was followed by terrestrial globalization, when the earth, not the cosmos, took center stage as the sphere containing life. Whereas celestial globalization can be defined as the rationalization of the universe via reflection, terrestrial globalization can be defined as the rationalization of the earth's surface via exploration and discovery. Increasingly, thought turns to smaller and smaller spherical forms. As we enter the global era, the great world interior takes center stage. The embryo of this is the Crystal Palace, built in Hyde Park in London in 1850, and opened to the public the next year. The Crystal Palace, designed by Joseph Paxton, housed the Great Exhibition of 1851. 
Constructed with plate-glass and cast-iron, it was literally an immense interior encompassing 990,000 square feet. Inside, the latest inventions of the industrial era sat side-by-side with works of art, wildlife, flora, and fauna. It was an attempt to create an all-encompassing sphere, of bringing the globe totally inside. This immense interior heralded the idea that 'social life could only take place in an expanded interior, a domestically organized and artificially climatized inner space' (p. 171).

As Marie-Eve Morin (2009) insists, however, to understand our contemporary era one must also understand the relationship between the worldly interior and foam: 'While the worldly interior... is a singular and comprehensive concept that describes the situation for globality as a whole, the notion of foams... emphasises the irreducible plurality of the space of the 'globalised interior' (p. 63). If the world interior, represented by the Crystal Palace, is an expansive, allencompassing one - an absolute expanse - then foam is the formation of myriad intersecting spheres within the world interior - the renegotiation of relative space. The transition from the terrestrial sphere as an object of intervention to foams occurs at the height of modernization, when 'air supply ceases to be an unproblematic premise of life processes and enters its technological stage' (Slotderijk, 1999/2014, p. 964). Foam is, generally speaking, the conglomeration of individual bubbles. Each bubble has its own microclimate, its own air conditions, its own atmosphere, and yet these bubbles share walls with each other, intimating a 'co-fragility' of being. We construct the bubbles comprising foam to escape the bad air, but can never create a pure inside (as we construct our spheres in those conditions handed-down to us from the past and outside).

The classroom for us stands as a microsphere, as a representative educational bubble within a conglomeration of foam. Conceptualizing it as such turns our attention to the productive and active roles of actual and metaphorical educational atmospheres. The classroom is an ephemeral sphere, one that enables and is sustained by the encounter. Classrooms give immunological protection from the outside at the same time as they aim toward their own bursting and absorption into that outside, as its walls collapse and lean into other bubbles in the foam-structure. Year after year, multiple atmospheric bubbles are co-produced in the same absolute space of the classroom as different bodies occupy them, as social transformations take place within the school and society, and as different pedagogies materialize within their shifting walls. While Sloterdijk's sphereology provides a useful frame for the classroom atmosphere, it remains somewhat abstract and technological. How is it that, as the interior of the classroom contains us, we also contain others? What is the relationship between outside and inside? Why, other than issues of health and quality, is air so important in the bubble of the classroom? Moreover - and tying these questions together - what might a pedagogical theory that attends to the classroom atmosphere or educational atmosphere look like, and how might this theory help us reconceptualize the space of the classroom? To respond to these questions, we weave together the thought of Luce Irigaray, Marshall Berman, Teresa Brennan, and Confucius. Through the first two theorists we construct the literal components of the classroom atmosphere, and through the latter two we construct a wind-pedagogy praxis oriented toward the maintenance of the classroom bubble and educational atmosphere.

\section{Aerial education}

Luce Irigaray (1983/1999) conceptualizes air as not only an envelope that contains and protects, but as a constituting and enabling materiality. Like Sloterdijk, her theorization emerges as a 
critique of Heidegger, although her critique builds on the absence of sexual difference in beingin-the-world. Her book, The forgetting of the air in Martin Heidegger is framed as a critique of Heidegger's insistence on the ground as the base or foundation of Being and beings, as that which enables thought. Irigaray charges Heidegger of forgetting a range of elements, including air. She insists that it is foundationally air, and not the ground, that is the basis of being-in-theworld.

But light comes about only in virtue of the transparent levity of air. Light presupposes air. No sun without air to welcome and transmit its rays. No speech without air to convey it. Day and night, voice and silence, appear and disappear in air. The extent of space, the horizons of time, and all that becomes present and absent within them are to be found gathered together in air as in some fundamental thing. (p. 166-167)

Air is that which encircles, closes in on, and defines the ineffability of being, and that which from being springs; it is the 'condition of possibility, the resource, the groundless ground' (p. 5) of being. Irigaray poses the air as both a thing and as a representative of feminine sexual difference, for it is the woman who gives air in the first instance as 'fluid matter carried by the blood she gives' to the fetus (p. 28). It is the woman who gives first by giving air, the air that in turn allows for the human to enter into the vast expanse.

For the purposes of this article, we are mostly concerned with the effect of prioritizing the air for educational philosophy. The primary move this helps us make is one away from metaphysics and toward a fluid, dynamic, open, and opaque materialism. Air is, after all, a material necessity that sustains life; it has a chemical composition, we can delineate its components, break it down (although it is never just a simple matter of combinations of oxygen and nitrogen). We can trace it and the networks it creates. Yet as a groundless element, air constantly and endlessly eludes us. It is 'irreducibly constitutive of the whole,' yet it 'compels neither the faculty of perception nor that of knowledge to recognize it. Always there, it allows itself to be forgotten' (p. 8):

The being never enters into presence in the same air...nothing ever occurs in the same place, that in each instant man changes his air, that he disappears-reappears all the time, that his becoming obliterates, and, moreover, corrupts, the air where he takes place, the air thanks to which he entered into presence. (p. 163)

Irigaray insists that the air escapes our comprehension and is, in the last instance, truly unrepresentable, it is an opacity instilled in the heart of being and one that keeps the heart beating. However, while she is correct that Heiddeger neglects the air, it is clear that Irigaray takes the air for granted, as something that is always-already there, and this limits a materialist approach to the air, for the air is never just there but is always the result of production. There are times when the air is not there, when it is withheld and sucked out (for example, in chemical weapons attacks, in instances of choking, etc.). Thus, while Irigaray helps us consider the air as a foundational component of life and thought, we have to turn elsewhere to develop a materialist approach, to consider how political economy and historical forces produce the air.

For Marshall Berman the air encompasses all manner of social transformations, providing a figure for understanding modernity in its richness and antagonism, its potential and hazard. Picking up on Marx and Engels' line about how, in capitalism, 'all that is solid melts into air,' 
Berman (1982) articulates a melting dialectic that 'pulls like an undertow against the more 'solid' Marxian visions we know so well' (p. 89). Capitalism doesn't constantly transform just the means of production, he writes, but also social relations themselves. As such, in order for individuals to survive we must ourselves become fluid. This creates an openness that can breed revolutionary potential, for as we become used to, and even begin to desire, constant change, why would we conform to the permanent roles assigned to us by bourgeois society? In the world of capital, we become 'dimly aware of all we might be together, ready to stretch ourselves to grasp new human possibilities, to develop identities and mutual bonds that can help us hold together as the fierce modern air blows hot and cold through us all' (p. 129). Berman calls on the air as a metaphor for modernity, capitalist development, and revolutionary change. Thus, he gives us a materialism that emphasizes the productive forces, but we still need to read it through Irigaray's aerial materialism. If all that is solid melts into air, where does the air go in turn? The air never disappears, it isn't annihilation or negation; it is something that contains us, enables us, allows being to subsist, facilitates encounters. When capital insists on melting the present into air, the present isn't obliterated, but rather adulterated, transformed. Here, we see that the classroom atmosphere cannot be disconnected from the outside, that the bubble or microsphere of the classroom isn't impermeable.

As we enter into the classroom we may note a change in the atmosphere, and Teresa Brennan's (2004) theory of affect helps us account for this. We not only feel the atmosphere, it literally enters into us. 'My affect,' she writes, 'if it comes across to you, alters your anatomical makeup for good or ill' (p. 74). Through smell, the other enters into our body. As one paradigmatic example, Brennan cites pheromones, faint excreted chemicals that communicate various things like excitement or fear to others (and are distinguished from hormones in that they act as external communicators). Pheromones 'act as direction-givers which, as molecules, traverse the physical space between one subject and another, and factor in or determine the direction taken by the subject who inhales or absorbs them' (p. 75).

The idea that the subject is invaded or traversed by others is one of her key arguments. Brennan gives the example of walking into a room filled with the affect of anxiety. Upon entering this room, she breathes this anxiety in: 'Something is taken in that was not present, at the very least not consciously present, before' (p. 68). Through the breathing-in of affects, others and the social enter into one's blood and one's makeup. Making a turn to linguistics, Brennan notes that the Spanish phrase 'Lo siento' means both 'I feel it' and 'I'm sorry,' and that the French verb, sentir, means 'to smell.' She suggests that undergirding these two translations is 'either that because we once knew that we felt the other's feeling by smell or because the body knows it still and seeks the word that will best describe its operations' (p. 149).

In visiting the history of the clinic, Brennan concludes that analysts have been acutely aware of the transmission of affect. She quotes Christopher Bollas's reflections: 'Or a patient may be so overwhelming, my anxiety so high, that I am more a creature of my respiratory system' such that 'I may be working with someone in my soma - in the stomach, the back, or in my respiratory system (p. 28). In linking his reception of affects to the respiratory system, Bollas is highlighting the central role that air plays in their circulation, linking the inhalation of the air to being taken hold of by others, and returning us once again to the co-construction of spheres and the handed-down circumstances under which such production takes place.

\section{Moving to the Chinese Wind as a Style of Reasoning}


So far we have drawn upon some Western literature to understand air as the literal and metaphoric components of any educational space, and as our first gesture toward building a dynamic air pedagogy. As compared to air as a literal-figural object, we now move to further philosophize air in relation to educational space as air in movement, giving rise to a new form of wind. In particular, we leverage the Chinese notion of 'wind' as a material, metaphorical, and more importantly as a style of reasoning that construes and constructs the Confucian space of teaching, learning, and teacher-student engagement in its broadest sense. In so doing, we hope to explicate and historicize a physical-metaphysical wind, a wind-pedagogy, as a particular cultural mode of thinking which provides important implications for and enriches the construction of an educational microsphereology built upon a Western air conditioning.

Wind is most popularly defined as 'wind in movement,' morphologically reminding us of the gentle spring breeze, the angry storm wind, or the biting winter gust. Cross-culturally, wind connotes a life-generating force-breath-spirit, a sign of bodily sickness and healing, and a natural-turned-cultural concept (Dallair, 2011; Hsu, 2007). However, the Chinese 'wind' enunciates much more than the above literal or figural definitions. As a cultural style of reasoning and as something even primordial than $q i$, the Chinese wind blows into the domains of space, agriculture, education, politics, poetry, and the medical body (Kuriyama, 1994). Defined as 'wind blows, and insects get germinated, hatched, and transformed within 8 days' (Shuowenjiezi, the first comprehensive Chinese dictionary), 'the fascination of the Chinese winds lay in their power to transform' (Kuriyama, 1994, p. 23, emphasis added). With this

transformational sense, the wind connects Confucian teaching, governing, space, and body into a grid of intelligibility, ordering the ways Chinese teaching, learning, and teacher-student relation have been thought about and acted upon over the past two millennia. In this sense, we argue this Chinese 'wind' can be viewed as a signature language of Chinese Confucian education, similar to the notion of Bildung for German education.

This Chinese wind-education association has gone largely unnoticed inside and outside of China. This neglect is in part due, we suspect, to a modern representational style of reasoning. Even though discourses like school wind, teaching wind, learning wind, party wind, and social wind are prevalent in current China, they are mostly interpreted as linguistic metaphors, transliterally meaning school atmosphere, teaching manners, learning styles, party morale, and social ambience. The beginnings of a project of reclaiming wind-education-inspired by Heidegger and Foucault's thinking on language and discourse-have already been initiated. This project has discovered a wind-education interlock in Chinese thinking, which was found to be traceable to Confucius' educational vision as expressed in the Book of Change (Zhao, in press). This article, then, can be seen as a further theorization of Chinese wind and wind-education that not only digs deeper into Confucius' educational philosophy, but that also finds affinities and points of continuity between Chinese and Western pedagogies.

Please note we are exploring Confucian teaching and learning in a broad sense. Confucian learning is about becoming a noble and exemplary person (junzi) through life-long stone-cutting-like cultivation, through which those successfully cultivated can become scholarofficials to help govern others, the society, and universe. As Han (2013) puts it, Confucian human learning interlocks with, (re)-produces, and (re)-structures Confucian state building, and 'the Confucian state was a large-scale metaphorical school, on a different scale to the modern concept of the school as an institution, where the ruler-subordinator relationship was re-framed to that of the teacher-learner' (p. 57). Henceforth, Confucian teaching and learning are much broader than the modern delimiting psychology-cognition-based learning of individuals (Jarvis, 
2010). With this clarification, we explore two questions. First, how does the wind-style reasoning construe and construct ancient China's thinking on cosmology, tempo-spatiality, teaching, and governance? Second, how is it possible to materialize and prioritize wind and air as a genre of engagement in such a way as to reinvigorate their historical materiality in spatializing current education?

\section{Ancient Chinese Wind-Grid \& Confucius' Wind-Pedagogy}

The early Chinese culture features a 'correlative thinking' component (Graham, 1996) which, among other things, correlates the cosmological changes with human governance (Wang, 2000). The Chinese 'wind' provides a unique point to unpack such correlative thinking as the former grids ancient Chinese reasoning on tempo-spatiality, musical tones, song-poetry, teachinggovernance, and cultural ambiences. To the extent that such a correlative style of thinking breaks apart a Western principle of ordering and classifying things (Foucault, 1973), we unpack this Chinese wind-grid not only to explicate its significance for rethinking educational air, space, and pedagogy, but also to explode the natural-cultural and material-conceptual boundary tropes.

First of all, the Chinese wind explodes a natural-cultural boundary. As a material thing, say, the breath exhaled by the universe, wind functions as a vitalizing force in that when winds blow in their proper seasons, the creatures of the world are able to procreate and grow (The Book of Changes). Furthermore, the material wind surrounds, contains, imprints on, and makes humans into relate-able subjects in a shared interior such that humans are geographically tempered and toned. The Han Dynasty book, Records on Geography (around 93 AD) says

people have strong, soft, tempered and hurried tones and sounds which are concomitant to the natural wind and qi of the local water and earth. All this is called wind. Likes and dislikes, taking and giving, moving and rest are dependent upon the feelings and desires of the rulers and so are called customs.... Sage-rulers are supposed to transform it by harmonizing temperedness and hurriedness, thus centralizing the strength and softness. Confucius says that 'changing winds and transforming customs, nothing works better than music.' (Cited in Lewis, 1990, pp. 215-216)

This narrative not only depicts a correlation between the natural winds, qi, water, earth, and the human temperaments, but also delineates wind as a space where the state of teaching and governing encounter each other. Material winds and qi get into the human body and mold the bodily temperament, which is in turn expressed in the form of music or song-poetry. In other words, geographical winds, human temperaments, and cultural ambiences are constitutive of one another, and by listening to the regional song-poetry one can tell its subjects' temperaments and cultural ambiences as an effect of the state-teaching and governing. For the example, the Zhou kingdom sends music masters-officials to collect the winds from the local areas and adapt them into the Zhou imperial court ritual music so that the royal rulers could observe the local winds and henceforth know the local cultural ambiences.

Second, this wind-song correlation foregrounds the Chinese wind not merely as a thing or concept, but as a governing style of reasoning, which also correlates and structures tempospatiality and state governing in early Chinese thought. Specifically, there are eight winds, eight spatial directions, eight musical tones, and eight sub-seasons, all ordered along a corresponding principle. The eight spatial directions - east, southeast, south, southwest, west, northwest, north, 
and northeast—blows eight different kinds of wind, each wind ruling a sub-season (around 45 days). For example, the first 45 days of the new year that is ushered in by the full moon are ruled by the northeast wind, with each subsequent period of 45 days being governed by one directional wind moving clockwise around the compass. In this way, the ordering of wind is set up, and the nature of myriad things are established, each has its own duties and should not interfere with each other (Baihutong-bafeng). From this we can draw a wind-grid that structures and correlates calendrical timing, space, musical tones, and human activities such that humans are to follow, be attuned to, and co-respond to cosmological changes.

Third, the correlation between cosmological winds and human governance is further embodied in Confucius' educational vision built upon an image of wind blowing over the earth. This image comes from a specific Yijing hexagram, named guan (observation), which depicts a scenario of a King with a big head performing a highest-ranking ritual in front of his observing subjects. With that, Confucius adds one commentary statement and envisions it into an ideal teaching and learning movement. Confucius builds his vision on four themes or conditions (Zhao, 2017). First, the King-teacher is an exemplar of virtue. Second, this observation is multilayered with the King observes the Dao movement on the top and the subjects observe the King from below. Third, both layers of observation follow a modeling and imitating principle. Fourth, it is the transformational sense of wind that Confucius mobilizes as an image and effect of his teaching-learning movement. This is what we mean by Confucius' wind-pedagogy.

With the above unpacking, we bracket wind as a material thing and a modern linguistic signifier. Rather, we problematize the historical-cultural construction of wind as a style of reasoning which orders the material wind as it is and in relation to tempo-spatiality, music, songpoetry, teaching, and governance. This new perspective helps to keep us from the trap of philology and a signifier-signified mode of representation that may possibly hinder the theorization of wind, air, or atmosphere as an ordering mechanism, and not merely a constitutive component, of an educational sphereology. In such a trap of philology we presume the a priori existence of grammatical arrangements in a language for what can be expressed in it and henceforth seek out its grammatical/semantic meaning (Foucault, 1973). By a conceptual signifier-signified style of reasoning, we mean that knowledge is generated largely through an ideal yet delimiting relay-play of concepts and ideas severed from material things.

This bring us back to the fact that wind-discourses are prevalent in current Chinese schooling and society as embodied in the motto of school wind, teaching wind, and learning wind. Yet, the wind-education association is largely unnoticed since they are mostly treated as metaphors, translated as school atmosphere, teaching styles, and learning manners. Then what could be the historical conditions that have engendered such a transfiguration of learning wind as a metaphor? More importantly, how is it possible to materialize and prioritize wind and air in spatializing current education?

\section{Mao's 'Learning Winds' in the 1940s as a Caveat}

Now let's turn to Mao's wind-regulation discourse in the $1940 \mathrm{~s}$, wherein we find a most recent prototype for today's thinking on school-wind discourse. In other words, the modern way of reasoning school wind (xuefeng) as a concept with semantic fillers such as 'being diligent, questioning, thinking and creative' can be traced directly back to Mao's wind-regulation discourse, albeit then with different semantic fillers. Here is Mao's definition: Xuefeng is not that of school but of the whole Party. It is a thinking method issue of $A, B$, and $C$, an attitude issue of 
how we treat Marx-Leninism, a working attitude issue of all party members (1942). With such a conceptual mode of reasoning, the inherent texture and tones of Chinese wind and its literal association with teaching and learning are nowhere visible and audible.

A brief note on Mao's wind-regulation is needed here. It starts with a learning call commanding all the Chinese Communist Party (CCP) cadres in the Yan'an revolutionary area to ruminate over the 22 designated directives, all published in CCP's then daily newspaper Jiefang Ribao, including Mao's three speeches, Regulating Three Winds, Opposing Party Wind, and Reforming our Learning. Cadres were directed to use these readings as norms for conducting merciless confessional self-reflection toward becoming a transformed new person. Retrospectively also called Thought Reform Movement, it is claimed to have achieved a revolutionary success in transforming and remodeling the thought of the whole CCP, paving a smooth way for Mao's subsequent Extermination Movement of the Others within the Party and finally winning Mao his leading power within the Party (Gao, 2000).

Mao's pedagogical strategies in this learning movement are as follows: A 'need' for selfreflection is first created by Mao's assertion that some defective winds (i.e., ways of thinking) exist among many intellectual party members (Zhao, 2015). His 'defective' judgment is further legitimized by asserting Marxism-Leninism, Unifying Theory and Practice in One, as the only truth in re-defining and measuring his concepts of 'true knowledge and real intellectuals.' Through making such radical yet self-rationalized judgment as 'many so-called intellectuals actually have less knowledge than peasants and workers,' a public humiliation and an obligation of self-reflection are invoked on intellectuals. Finally, Mao provides the 'right' learning method and guiding principles for how to conduct self-reflection mercilessly so that one can cut off one's old entire being toward becoming a transformed 'new person.' Mao's creative governing strategy, namely, requiring learners to share their confession in public meetings, encounters a huge psychological obstacle, since sharing confessional secrets means losing one's face in public and is humiliatingly shameful to most Confucian Chinese intellectuals. However, such deeprooted Confucian conceptualization of shame is discursively reframed as a glorious joy and a moral responsibility of any 'qualified' CCP member.

\section{New Gesture: Toward Embodying/Enacting a Communal Classroom Ambience}

Whereas Confucian pedagogy harnesses the primordial wind, Mao's early pedagogy attempts to regulate that wind in the service of a specific ordering of subjects. Thus, our point in detouring briefly through Mao's wind-regulating movement is to caution against deploying a notion of the educational atmosphere toward prescriptive ends, as if the classroom air could be reduced to a technique or technology that could be altered, tweaked, or otherwise modulated to achieve a predetermined goal. This is not to dismiss the idea that education should have objectives, of course, but rather to insist that such reductions return us to the cold stream of materialism that Berman (1982) denounces so passionately. This cold stream is represented by economistic distortions of marxism that would attempt to curtail it to a purely detached scientific analysis, or in Mao's wind-regulation, a monolithic ontological order. Instead, Berman argues that marxism provides 'a new image of the good life: not a life of definitive perfection... but a process of continual, restless, open-ended, unbounded growth' (p. 98).

Interestingly, we might turn to the Great Proletarian Cultural Revolution as an example of such a warm atmosphere. Here, Mao breaks from the Leninist principle of democraticcentralism, which confine criticism to inner-party meetings, and augments his wind-regulating 
pedagogy. The Cultural Revolution emerges from the struggle taking place in the Chinese Communist Party between the "capitalist roaders" and the socialists: should market mechanisms or social planning guide development? Rather than engage in debates or politicking, Mao's grouping put the question to the masses. While they did have a destination in mind, they didn't impose it through the military, the police, or the courts. In 1966, the Central Committee of the Party proposed sixteen guidelines for the revolution. These guidelines can be understood as an injection of wind-pedagogy into the Chinese Revolution. There is the dual movement from top to bottom, from leadership to masses. In particular, the masses are called to "put daring above everything else" and to "Caste out fear. Don't be afraid of disturbances" (Central Committee of the Chinese Communist Party, 1966). Here, the masses are the wind blowing over the Earth.

Our educational sphereology and the materialist pedagogy of the wind that it inaugurates, then, is not rooted in a never-ending unfolding of logic or in the sublimation or supersession of opposites. Neither does it occupy one side of the physics/metaphysics or nature/culture binary. The air isn't easily understood or experienced with rigid — or 'rigorous' — analytical or ontological frameworks. In taking the educational atmosphere seriously, then, we are left with no choice but to develop a fluid, dynamic, open, and opaque materialism. What we have is the air and the wind conceived of not as literal or figural elements, but rather as an educational mode of life and a mode of educational life. As we co-construct our educational atmospheres, we are called to be attentive to the ways in which we are traversed by others, by history, by the world, in ways that are always powerful but often barely perceptible.

Both air and wind are morphologically dynamic, rather than fixed entities. Their fluid intersections with human bodies disrupts the enclosure of human subjectivities as a cognitive construct. This shared fluidity of air and wind can be treated as an educational mode of life and a mode of educational life. Such a treatment further foregrounds a shared materialist grounding of being in and being with behind the Chinese wind and the Western air, both of which have two significant implications for enacting/embodying a tempo-spatial dynamic aerial pedagogy. First, the fact that students are subsumed in a being-in-the air/wind melts ego-centered subjectivity into material ontological co-being, ontological in the sense that human beings are being with each other not just cognitively but also material-bodily. Seen this way, individual learning which is prioritized in today's classrooms becomes a communal study wherein students are ecologically inter-related and ethically traversed-moved with each other through the air, the affect, the pheromones, and the subsistent fluid, dynamic, open, and opaque tempo-spatiality of the each other.

Second, this aerial ontological being-in and being-with can't be assumed to already be there, as it is an effect of historical-cultural-political negotiations and needs to pedagogically cultivated, constructed, and reconstructed dynamically. Subjectivity is cut across and through by identity, history, economics, in a word: materiality. Engaging this materiality pneumatically, however, positions it as open to unexpected transformations and penetrations. We are not on solid ground here, and so are left with a series of questions. For example, how is it possible for educational subjects to see, enact, and embody our ecological co-being with materiality in educational spaces? How do we revise anthropological dominance in educational ambience? How can we institute our own cultural revolutions in our educational and political movements?

\section{References}


Berman, M. (1982). All that is solid melts into air: The experience of modernity. New York: Penguin Books.

Brennan, T. (2004). The transmission of affect. Ithaca: Cornell University Press.

Central Committee of the Chinese Communist Party. (1966). Decision of the Central Committee of the Chinese Communist Party concerning the Great Proletarian Cultural Revolution. Retrieved from: http://www.massline.org/PekingReview/PR1966/PR1966-33g.htm.

Dallair, M. (2011). Teaching with the Wind: Spirituality in Canadian Education. University Press of America, Inc.

Ferrare, J.J., \& Apple, M.W. (2010). Spatializing critical education: Progress and cautions. Critical Studies in Education, 51(2), 209-221.

Ford, D.R. (2016). A pedagogy for space: Teaching, learning, and studying in the Baltimore Rebellion. Policy Futures in Education, 14(2), 176-193.

Ford, D.R. (2017). Education and the production of space: Political pedagogy, geography, and urban revolution. New York: Routledge.

Foucault, M. (1973). The Order of Things: An Archaeology of the Human Sciences. NewYork: Vintage Books.

Gao, H. (2000). Hongtaiyang shi zenyang shengqi de: Yan'an zhengfeng yundong de lailongqumai [How the red sun rises: the complete process of yan'an wind-regulation movement]. Hongkong: Hongkong Chinese University Press.

Graham, A. C. (1986). Yin-yang and the nature of correlative thinking. Singapore: The Institute of East Asian Philosophies.

Han, S. (2013). Confucian States and Learning Life: Making Scholar-Officials and Social Learning a Political Contestation. Comparative Education, 49(1): 57-71.

Hsu, E. (2007). The Experience of Wind in Early and Medieval Chinese Medicine. Journal of the Royal Anthropological Institute (N.S.): 117-134.

Hung, R., \& Stables, A. (2011). Lost in space? Located in place: Geo-phenomenological exploration and school. Educational Philosophy and Theory, 43(2), 193-203.

Irigaray, L. (1983/1999). The forgetting of the air in Martin Heidegger (trans. by M.B. Mader). Austin: University of Texas Press.

Jarvis, P. (2010). Adult Education and Lifelong Learning: Theory and Practice. London: Routledge.

Kuriyama, S. (1994). The Imagination of Winds and the Development of the Chinese Conception of the body. In Zito, A \& T. E. Barlow (Eds.), Body, Subject, and Power in China (pp. 23-41). Chicago University Press.

Lewis, M. E. (1990). Sanctioned Violence in Early China. State University of New York Press.

Mao, Z. D. (1942). 'Regulating three winds' (zhengdun xuefeng, dangfeng, wenfeng), Jiefang Ribao, April 27, 1942.

Marx, K. (1963). The eighteenth Brumaire of Louis Bonaparte. New York: International Publishers.

Morin, M-E. (2009). Cohabiting in a globalised world: Peter Sloterdijk's global foams and Bruno Latour's cosmopolitics. Environment and Planning D: Society and Space, 27(1),

Peters, M. (1996). Poststructuralism, politics and education. Westport: Bergin \& Garvey.

Ringrose, J. (2011). Beyond discourse? Using Deleuze and Guattari's schizoanalysis to explore affective assemblages, heterosexually striated space, and lines of flight online and at school. Educational Philosophy and Theory, 43(6), 598-618. 
Sloterdijk, P. (1998/2011). Spheres I: Bubbles: Microsphereology (trans. by W. Hoban). Los Angeles: Semiotext(e).

Sloterdijk, P., \& Heinrichs, H-J. (2001/2011). Neither sun nor death (trans. by S. Corcoran). Los Angeles: Semiotext(e).

Sloterdijk, P. (2003/2013). In the world interior of capital: For a philosophical theory of globalization (trans. by W. Hoban). Los Angeles: Semiotext(e).

Sloterdijk, P. (1999/2014). Spheres II: Globes: Macrosphereology (trans. by W. Hoban). Los Angeles: Semiotext(e).

Usher, R. (2002). Putting space back on the map: Globalisation, place and identity. Educational Philosophy and Theory, 34(1), 41-55.

Wang, A. (2000). Cosmology and political culture in early China. Cambridge University Press.

Wubbena, Z. (2017). A pedagogy for space: Visually framing the 2011 Chilean student movement. Policy Futures in Education, 15(4), 460-480.

Zhao, W. (2015). Historicizing Chinese self-reflection as confessional technology of self: Mao's "wind-regulation" movement and Confucian self-cultivation. In Andreas Fejes and Katherine Nicoll (Eds.), Foucault and a Politics of Confession in education, pp. 175-188. Routledge, London and New York.

Zhao, W. (2017). Re-invigorating the being of language in international education: Unpacking Confucius' 'wind-pedagogy' in Yijing as an example. Discourse: Studies in the Cultural Politics of Education. DOI: 10.1080/01596306.2017.1354286

Zhao, W. (in press). China's Educational Language: Education, Curriculum, and Knowledge in a Cross-Cultural Context. New York: Routledge. 